\title{
Enhancing fish productivity through pen culture: a case study in Sareni wetland of Uttar Pradesh
}

\author{
A. ALAM, K. D. JOSHI, S. C. S. DAS, D. N. JHA, K. SRIVASTAVA, V. KUMAR AND \\ B. K. BHATTACHARJYA* \\ ICAR-Central Inland Fisheries Research Institute, Regional Centre, 24-Pannalal Road, Allahabad - 211002 \\ Uttar Pradesh, India \\ "ICAR-Central Inland Fisheries Research Institute, Regional Centre, Housefed Complex, Dispur \\ Guwahati - 781006 Assam, India \\ e-mail: absar_alam@rediffmail.com
}

\begin{abstract}
Pen culture for in situ raising of stocking material was conducted in Sareni Jheel, located in the Rae Bareli District of Uttar Pradesh. Sareni Jheel, being rich in organic carbon (4.5\%) and nutrients, higher values of silt $(29 \%)$ and clay (15\%) were recorded. Rich oxygen levels, alkaline $\mathrm{pH}$, high organic matter, moderate to high chemical parameters suggested moderately productive nature of this wetland. Pen with high-density polyethylene (HDPE) net was installed in an area of 0.1378 ha and stocked with advanced fry of the Indian major carps, rohu Labeo rohita and catla Catla catla in the ratio of 1:1@ @ 25 nos. m². No significant changes in water quality parameters were noticed within and outside the installed pen. Mean weight at stocking of rohu and catla was $2.88 \pm 1.41 \mathrm{~g}$ and $2.1 \pm 1.16 \mathrm{~g}$, which increased to $57.2 \pm 13.84 \mathrm{~g}$ and $67.38 \pm 25.79 \mathrm{~g}$ respectively, in 120 days. The average feed conversion ratio (FCR) recorded was 1.08 with overall survivability of $69.52 \%$ in rohu and $74.74 \%$ in catla. Benefit-cost ratio and return on investment were calculated as 1.69 and 0.69 , respectively. Intervention through pen culture resulted in the increase in fish productivity of Sareni Jheel from 310 to $833 \mathrm{~kg} \mathrm{ha}^{-1}$.
\end{abstract}

Keywords: Benefit-cost ratio, Fingerling, Fry, Growth, Pen culture, Sareni Jheel, Survivability

\section{Introduction}

India is bestowed with vast freshwater wetland resources (0.55 million ha), locally known as beels, mauns, chaurs, pats, tals and jheels in various states of the country. These habitats are integral part of the river complex. Irrigation projects and flood control measures have destroyed many of these water bodies which were nursery and breeding grounds of Indian major carps (IMCs) (Sinha and Khan, 2001). A number of wetlands got permanently disconnected from the parent river (closed beels) while some of them still maintain their connectivity (open beels). It is estimated that freshwater wetlands support $20 \%$ of the known range of biodiversity in India (Deepa and Ramchandra, 2000). This huge biodiversity reserves provide necessary launching platforms for increasing fish production. The ecology and productivity of wetlands in different parts of the country has been extensively studied (Pathak et al., 1985, 2002, 2004; Jha, 1989, 1997; Pathak,1989, 1990; Sugunan, 1995, 1997; Vass, 1997; Kumar and Joshi, 2008; Joshi and Kumar, 2009). The state of Uttar Pradesh has sizeable area of 1.52 lakh ha under wetlands (Pathak et al., 2004), but the level of interventions to enhance productivity of these water bodies remained almost nil or insufficient due to non-existence of location specific management protocols. The production potential in different wetlands of the country has been estimated to range between 1000 and $1500 \mathrm{~kg} \mathrm{ha}^{-1}$ (Pathak et al., 2004; Sharma et al., 2010). Lack of understanding of the ecological principles, especially productivity characteristics and improper management has resulted in rather low yield (100 to $200 \mathrm{~kg} \mathrm{ha}^{-1}$ ) from most of the wetlands of the country (Pathak et al., 2004; Anon., 2011b), inspite of the high production potential. The greater utilisation of energy reserve by fishes feeding at higher trophic levels or that by uneconomical species resulted in lower average harvest (Pathak et al., 2002). This could be compensated by stocking fishes that feed at lower trophic levels (Pathak et al., 2002). Pen culture is an economically viable technology for in-situ raising of stocking material (Banerjee and Pandey, 1978; Vass, 1997; Katiha et al., 2005; Gorai et al., 2006; Aparna and Hassan, 2013; Chandra et al., 2013). Releasing fingerlings raised in pen in open waters, have shown better growth and survivability (Gireesha et al., 2003; Aparna and Hassan, 2013). This study on rearing fry of rohu and catla to fingerling stages in a pen installed in the Sareni Jheel in Rae Bareli District, Uttar Pradesh, involving unskilled labour was conducted aimed at enhancing fish productivity of the wetland ecosystem. 


\section{Materials and methods}

The present study was undertaken in Sareni Jheel, which is a perennial and closed type of wetland located in the Sareni Village of Rae Bareli District, Uttar Pradesh (Fig.1).

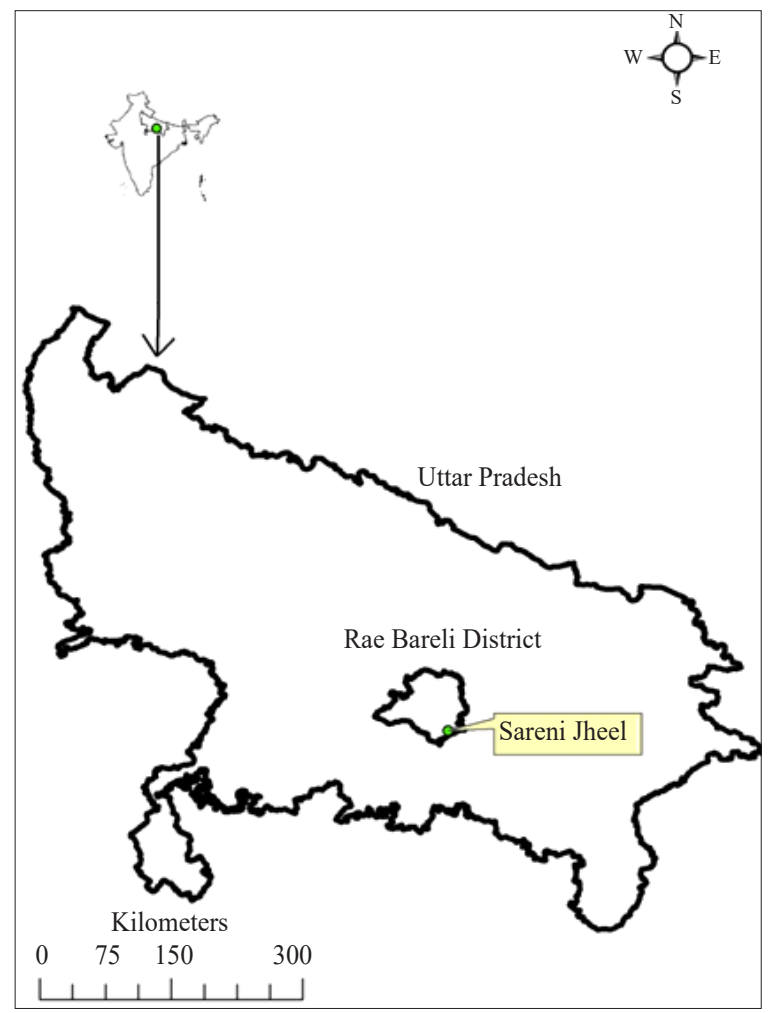

Fig. 1. Location of the Sareni wetland in Uttar Pradesh, India

Baseline information on water spread area, fish yield $\left(\mathrm{kg} \mathrm{ha}^{-1}\right)$, intensity of weed infestation and fisheries were collected from the stakeholders of the jheel. Ichthyofauna were collected by experimental fishing using different types of gears including gillnets, cast net and dragnets of different mesh sizes and other locally available gears. The materials used for the pen construction were: fencing screen of HDPE of width $1.83 \mathrm{~m}$ with mesh size of $5 \mathrm{~mm}$; bamboo poles of length $2.5 \mathrm{~m}$; nylon webbing of one foot width (mesh size: $5 \mathrm{~mm}$ ); foot rope of $3 \mathrm{~mm}$ dia and twine of 1 $\mathrm{mm}$ thickness. Marginal area of the jheel was considered for pen installation, taking into account the difficult terrain and poor transport systems. The exact position of the pen was demarcated by driving bamboo poles in each of the four corners. Ropes were marked at intervals of $2 \mathrm{~m}$ and tied to poles at the opposite corner just above the waterline. Bamboo poles were fixed by driving them into mud at $2 \mathrm{~m}$ interval, following the markings in the rope. The above procedure was repeated on the other two sides, with the fourth side represented by the land. To the bottom of the HDPE screen, nylon webbing of one foot width with sinkers at interval of $10 \mathrm{~cm}$ was attached to prevent escape of stocked fishes from the pen. The screen so prepared was then erected on the outer side of bamboo followed by the insertion of the lower portion of the net into the mud. The screen was then tied to the bamboo poles at two to three points. The bamboo poles were then staked in the middle of the two poles on the other side of the screen, which was then tied to the poles using twines at two points. Repeated netting was done within the pen to remove weed fishes. Samples of water and sediment were collected at monthly intervals, both from inside and outside the pen and analysed follwoing standard procedures (APHA, 2005). Plankton samples were collected from inside and outside the pen by filtering 501 of water using a plankton net to a volume of $50 \mathrm{ml}$ and fixed in $4 \%$ formalin. Planktonic abundance was recorded as nos. per liter. Mean of the physico-chemical parameters and the plankton abundance inside and outside the pen were subjected to t test at 5\% level of significance. The total area of the pen was $1378 \mathrm{~m}^{2}$ $(52.0 \times 26.5 \mathrm{~m})$. The pen was then stocked with advance fry of Catla catla (catla) and Labeo rohita (rohu) having average weight of 2.1 and $2.88 \mathrm{~g}$ respectively in the ratio of 1:1@25 nos. $\mathrm{m}^{-2}$. The fishes were fed with rice bran and mustard oil cake (1:1)@3-5\% of the body weight in addition to natural food available in the pen. The growth rate of carps in the pen was monitored by sampling at 30 days interval using cast net to ascertain their health status and to adjust feed ration in relation to the changes in the biomass of the cultured population in the pen. Length and weight of the sampled fishes were recorded and the growth pattern was statistically tested using one way ANOVA. Growth during the culture period was assessed as:

$\begin{aligned} & \text { Body weight gain } \\ & \text { (g per months })\end{aligned} \quad=\begin{aligned} & (\text { Final weight-Initital weight }) / \text { culture } \\ & \text { period in terms of months }\end{aligned}$
$\begin{aligned} & \text { Specific growth } \\ & \text { rate }(\mathrm{SGR})\end{aligned}$
$\begin{aligned} & \text { Feed conversion } \\ & \text { ratio }(\mathrm{FCR})\end{aligned}$

After a culture period of 120 days ( $\left(1^{\text {st }}\right.$ December 2013 - $31^{\text {st }}$ March 2014), the carp juveniles were harvested and released into the jheel for stock enhancement. Economic analysis of the pen culture operation was done to estimate the benefit-cost ratio (BCR) and return on investment.

\section{Results and discussion}

Sareni Jheel has a total water spread area of 18 ha with an average depth of approximately $0.94 \mathrm{~m}$. The wetland is moderately infested with aquatic weeds, the dominant among them being Hydrilla, Ceratophyllum, Eichhornia and 
Nelumbo. A total of 31 fish species were documented from the jheel. The fish yield recorded during the preent study was around $310 \mathrm{~kg} \mathrm{ha}^{-1}$, inspite of the high production potential of 638-1327 kg ha-1 from wetlands of Uttar Pradesh (Pathak et al., 2004). Predatory fishes like Channa marulius, C. striata, C. punctata and Wallago attu and miscellaneous group of fishes viz., Puntius sophore, Pethia conchonius, Salmostoma bacaila, Amblypharyngodon mola, Trichogaster fasciata and Esomus danrica contributed significantly to the catch. The water quality and sediment quality recorded from the Sareni wetland prior to stocking are presented in Table 1.

Organic carbon $(4.5 \pm 0.28 \%)$, available nitrogen $(560 \pm 6.78 \mathrm{ppm})$ and available phosphorous (51 $\pm 3.1 \mathrm{ppm})$ were observed to be quite high in the soil samples. This richness in the bottom soil might be due to deposits of the decaying organic matter. However11, the rich nutrient status of the soil was not reflected in the water phase, which showed deficiency in both the major nutrients (nitrate $0.12 \pm 0.05 \mathrm{ppm}$ and phosphate $0.06 \pm 0.04 \mathrm{ppm}$ ). This could be attributed to large amount of nutrients being taken up by the growing macrophytes, which remain locked in the bottom deposits following death of these macrophytes and effectively

Table 1. Sediment and water quality of the Sareni Jheel (Mean \pm SD)

\begin{tabular}{ll}
\hline Parameters & \\
\hline Sediment quality & \\
\hline Sand (\%) & $56 \pm 2.89$ \\
Silt (\%) & $29 \pm 1.15$ \\
Clay (\%) & $15 \pm 1.73$ \\
pH & $6.95 \pm 1.28$ \\
Sp. Conductance ( $\mu$ siemens cm $\left.{ }^{-1}\right)$ & $372.7 \pm 5.93$ \\
Free CaCO $(\%)$ & $1.25 \pm 0.07$ \\
Organic carbon (\%) & $4.5 \pm 0.28$ \\
Av. Nitrogen (ppm) & $560 \pm 16.78$ \\
Av. Phosphorus (ppm) & $51 \pm 3.1$ \\
\hline Water quality & \\
\hline Temperature $\left({ }^{\circ} \mathrm{C}\right)$ & $31 \pm 1.04$ \\
Transparency (cm) & $70.67 \pm 4.04$ \\
Dissolved oxygen (ppm) & $7.2 \pm 0.31$ \\
pH & $7.12 \pm 0.25$ \\
Total alkalinity (ppm) & $109.3 \pm 6.11$ \\
Sp. Conductance $\left(\mu\right.$ siemens cm $\left.{ }^{-1}\right)$ & $279.8 \pm 6.66$ \\
Total dissolved solids (ppm) & $159.11 \pm 4.58$ \\
Calcium (ppm) & $16.3 \pm 1.23$ \\
Magnesium (ppm) & $8.81 \pm 1.47$ \\
Total hardness (ppm) & $77 \pm 3.0$ \\
Chloride (ppm) & $15.15 \pm 0.82$ \\
Dissolved organic matter (ppm) & $1.89 \pm 0.10$ \\
Nitrate (ppm) & $0.12 \pm 0.05$ \\
Phosphate (ppm) & $0.06 \pm 0.04$ \\
\hline
\end{tabular}

removed from the water circulation for longer duration. The nutrient status of sediment with distinct alkaline character and rich oxygen content of the water indicated that the water body was moderately productive. Plankton population ranged between 210 and $280 \mathrm{ul}^{-1}$ with mean of $223 \mathrm{ul}^{-1}$ in Sareni Jheel. Analysis of variance indicated that the plankton population size inside and outside the pen did not vary significantly ( $\mathrm{t}$ test, $\mathrm{p}>0.05$ ). After stocking, the water and sediment quality within and outside the pen (Table 2) did not differ significantly ( $t$ test $p>.05$ ), indicating adequate water exchange through the enclosure walls.

Mean plankton abundance inside the pen was $40 \mu^{-1}$ and outside the pen it was $363 \mu^{-1}$ in Sareni wetland, showing significant difference ( $\mathrm{t}$ test, $\mathrm{p}<0.05$ ). The Indian major carps at their earlier stage are planktivorous (Anon., 2011a). The low abundance of plankton inside the pen might be due to the active grazing of the growing fry of catla and rohu on plankton. The FCR was found to be approximately 1.08. Since the fish is grown in natural conditions, it will be taking natural food also, which could be the resason for low

Table 2. Sediment and water quality parameters within and outside the pen $($ Mean \pm SD)

\begin{tabular}{lll}
\hline Parameters & Within pen & Outside pen \\
\hline Sediment quality & & \\
\hline Sand (\%) & $66 \pm 3.83$ & $66 \pm 2.89$ \\
Silt (\%) & $23 \pm 4.07$ & $24 \pm 1.15$ \\
Clay (\%) & $11 \pm 3.6$ & $10 \pm 1.73$ \\
pH & $6.74 \pm 1.06$ & $6.97 \pm 0.86$ \\
Sp. Conductance & $368 \pm 7.12$ & $384.2 \pm 6.23$ \\
( $\mu$ siemens cm $\left.{ }^{-1}\right)$ & & \\
Free CaCO $(\%)$ & $1.75 \pm 0.07$ & $1.75 \pm 0.06$ \\
Organic carbon (\%) & $1.95 \pm 0.24$ & $1.95 \pm 0.28$ \\
Av. Nitrogen (ppm) & $296 \pm 16.7$ & $313 \pm 14.2$ \\
Av. Phosphorus (ppm) & $39 \pm 2.1$ & $51 \pm 3.2$ \\
\hline Water quality & & \\
\hline Temperature ( $\left.{ }^{\circ} \mathrm{C}\right)$ & $22.43 \pm 0.53$ & $21.56 \pm 0.13$ \\
Transparency (cm) & $61.6 \pm 6.81$ & $56.6 \pm 7.2$ \\
Dissolved oxygen (ppm) & $6.69 \pm 0.46$ & $8.69 \pm 1.15$ \\
pH & $7.35 \pm 0.03$ & $7.85 \pm 0.02$ \\
Total alkalinity (ppm) & $191.33 \pm 1.73$ & $201.3 \pm 2.31$ \\
Sp. Conductance & $473.06 \pm 11.02$ & $480.27 \pm 9.51$ \\
$\left(\mu\right.$ siemens cm $\left.{ }^{-1}\right)$ & & \\
Total dissolved & $271.63 \pm 5.3$ & $274.93 \pm 4.4$ \\
solids (ppm) & & \\
Total hardness (ppm) & $186.87 \pm 18.47$ & $175 \pm 13.86$ \\
Dissolved organic & $5.3 \pm 0.09$ & $4.17 \pm 0.51$ \\
matter (ppm) & & \\
Nitrate (ppm) & $0.06 \pm 0.03$ & $0.08 \pm 0.04$ \\
Phosphate (ppm) & $0.014 \pm 0.03$ & $0.076 \pm 0.02$ \\
\hline & & \\
\hline
\end{tabular}


FCR. The survival rate and growth pattern of rohu and catla are illustrated in Fig. 2 and Table 3.

Significant difference in growth pattern was noticed (ANOVA, $\mathrm{p}<0.05$ ) in both catla and rohu. Rohu grew from $2.88 \pm 1.41$ to $57.72 \pm 13.84 \mathrm{~g}$ while catla grew from $2.1 \pm 1.16$ to $67.38 \pm 25.79 \mathrm{~g}$. Weight gain in the first three months of culture were comparatively lower than in the third month. Low temperature $\left(<20^{\circ} \mathrm{C}\right)$, which was below the optimum range of $24-30^{\circ} \mathrm{C}$ for warm water fishes (Anon., 2011c) would not have provided favourable conditions for ideal growth. The specific growth rate (SGR) recorded during the last month of culture was 72.7 and $79.52 \%$ in rohu and catla respectively. The survival rate recorded for rohu and catla was 69.52 and $74.74 \%$ respectively (Table 3 ) which was within the normal range reported for rearing of IMC fry to fingerling (Anon., 2011a).

There are only few reports on culture of IMCs for raising stocking material in the wetlands (Banerjee and Pandey, 1978; Bhaumik et al., 2000; Gorai et al., 2006; Bhattacharya

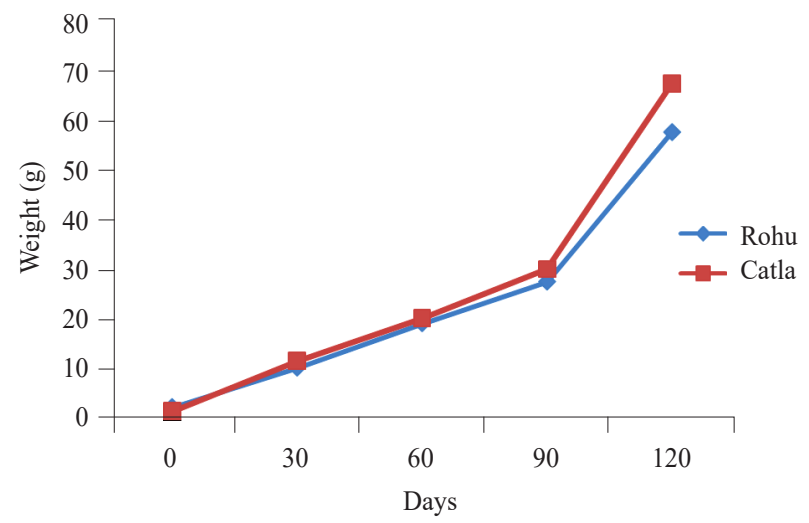

Fig. 2. Mean increase in total body weight (g) of rohu and catla in Sareni Jheel during 120 days culture period et al., 2010). Rohu, mrigal and silver carp grew from 50 to $71.5 \mathrm{~g}, 60$ to $74 \mathrm{~g}$ and 30 to $75 \mathrm{~g}$, respectively in 59 days of culture period with supplementary feeding rate at $4 \%$ of body weight (Bhaumik et al., 2000). Gorai et al. (2006) reported that catla, rohu and mrigal grew from initial body weight of $1.8,1.15$ and $1.15 \mathrm{~g}$ to $85.1,52.8$ and $42.9 \mathrm{~g}$ respectively in Goruchora wetland of-Assam within a rearing period of 145 days. Bhattacharya et al. (2010) and Gorai et al. (2010) successfully reared carp fingerlings as stocking material using pen in Damal and Samaguri beels of Assam with supplementary feeding of rice bran and mustard oil cake (1:1)@ $5 \%$ of the body weight.

The benefit-cost ratio (BCR) for the pen culture operation for a single crop was estimated as 1.69 which is in agreement with studies by Gorai et al. (2006) and Chandra et al. (2013) in wetlands of Assam. The return on investment estimated was 0.69 (Table 4).

Results of the study clearly indicated that this method of raising advanced fry to fingerlings in pen installed in wetland bodies could reasonably fetch high profitability. A total of 150 quintals of fish was harvested from the jheel between October and November 2014. Intervention through pen culture resulted in the increase in fish productivity of Sareni Jheel from 310 to $833 \mathrm{~kg} \mathrm{ha}^{-1}$. Raising fingerling as stocking material in pen aimed at stock enhancement in the open jheel during the present study, recorded higher rate of survivability, better growth rate and over-all enhancement of the fish productivity of the wetland. Raising fingerlings as stocking material with subsequent release can greatly help in bridging the gap between actual and potential productivity of fish yield in wetlands.

Table 3. Growth and survivability of L. rohita and C. catla in pen installed in Sareni Jheel during the 120 days culture period

\begin{tabular}{|c|c|c|c|c|c|}
\hline Days & 0 & $30(\mathrm{Dec})$ & $60(\mathrm{Jan})$ & 90 (Feb.) & 120 (March) \\
\hline \multicolumn{6}{|l|}{ Labeo rohita } \\
\hline Temp $\left({ }^{\circ} \mathrm{C}\right)$ & & 16.8 & 16 & 18.7 & 24.5 \\
\hline Mean weight (g) & $2.88 \pm 1.41$ & $10.75 \pm 6.41$ & $19.61 \pm 10.11$ & $27.9 \pm 11.99$ & $57.72 \pm 1$ \\
\hline Weight gain $(\mathrm{g})$ & & 7.87 & 8.86 & 8.29 & 29.82 \\
\hline Specific growth rate (SGR) & & 131.7 & 60.1 & 35.25 & 72.7 \\
\hline Survivability (\%) & & & & & 69.52 \\
\hline \multicolumn{6}{|l|}{ Catla catla } \\
\hline Mean weight (g) & $2.1 \pm 1.16$ & $12.15 \pm 6.86$ & $20.67 \pm 11.85$ & $30.42 \pm 13.31$ & $67.38 \pm 25.79$ \\
\hline Weight gain (g) & & 10.05 & 8.52 & 9.75 & 36.96 \\
\hline Specific growth rate (SGR) & & 175.5 & 53.1 & 38.6 & 79.52 \\
\hline Survivability $(\%)$ & & & & & 74.74 \\
\hline
\end{tabular}


Table 4. Economics of pen culture for raising advance fingerling from advance fry

\begin{tabular}{|c|c|c|c|}
\hline & Sareni Jheel & & \\
\hline Sl. No. & Particulars & Quantity & Amount (₹) \\
\hline \multirow[t]{4}{*}{ A } & Capital cost & & \\
\hline & Area $\left(\mathrm{m}^{2}\right)$ & 1378 & \\
\hline & Cost of pen construction & & 40340 \\
\hline & Cost of pen construction per crop & & 13446.67 \\
\hline \multirow[t]{11}{*}{$\mathrm{B}$} & Operational costs & & \\
\hline & Cost of fish fingerlings $(\mathrm{kg})$ & 90 & 22500 \\
\hline & Seed transportation cost & & 6150 \\
\hline & Feed (mustard oil cake + rice bran) cost $(\mathrm{kg})$ & 1612 & 32240 \\
\hline & Plastic ropes (bundal) & 1.31 & 295 \\
\hline & Labour cost in pen construction (no.) & 6 & 870 \\
\hline & Labour cost for carpenter (no.) & 3 & 900 \\
\hline & Cost for stocking and netting for removal of unwanted fishes & & 2000 \\
\hline & Charges for watch and ward, + daily feeding charges for 4 months & 4 & 14000 \\
\hline & Cost of harvest & & 1140 \\
\hline & Total & & 80095 \\
\hline $\mathrm{C}$ & Total costs $(\mathrm{A}+\mathrm{B})$ & & 93541.67 \\
\hline \multirow[t]{3}{*}{$\mathrm{D}$} & Gross income & & \\
\hline & Market price of & & \\
\hline & Fish yield of advanced fingerlings $(\mathrm{kg})$ & 1583.3 & \\
\hline \multirow[t]{4}{*}{$\mathrm{E}$} & Return (₹100 per kg) & & 158330 \\
\hline & Profit & & 64758.33 \\
\hline & B C Ratio (BCR) & 1.69 & \\
\hline & Return on investment (D/E) & 0.69 & \\
\hline
\end{tabular}

\section{Acknowledgements}

The authors are grateful to the Director, ICAR-CIFRI, Barrackpore for encouragement and guidance.

\section{References}

Anon. 2011a. Carp culture. In: Handbook of fisheries and aquaculture. Indian Council of Agricultural Research, $2^{\text {nd }}$ edn., New Delhi, p. 380-400.

Anon. 2011b. Floodplain wetlands of India. In: Handbook of fisheries and aquaculture. Indian Council of Agricultural Research. $2^{\text {nd }}$ edn., New Delhi, p. 275-301.

Anon. 2011c. Soil and water quality management in aquaculture. In: Handbook of fisheries and aquaculture. Indian Council of Agricultural Research. $2^{\text {nd }}$ edn., New Delhi, p. 591-622.

Aparna, R. and Hassan, M. A. 2013. Adoption of pen culture technology in the wetlands of West Bengal. Fish. Technol., 50: 342-346.

APHA 2005. Standard methods for examination of water and wastewater. $21^{\text {st }}$ edn., APHA AWWA, WPCF, Washington DC, USA.

Banerjee, S. R. and Pandey, K. K. 1978. Carp seed stocking in an oxbow lake of Champaran (Bihar) through rearing enclosure. J. Inland Fish. Soc. India, 10: 129-134.
Bhattacharjya, K. K., Yengkokpam, S., Kolekar, V., Gogoi, P., Sarma, K. K. and Dipesh, D. 2010. Pen culture for rearing carp seed in Damal beel of Assam, In: Das, M. K., Katiha, P. K., Mohanty, B. P., Manna, S. K. Majumdar, S., Sunita, P. and Srivastava, P. (Eds.), Book of Abstracts, $21^{\text {st }}$ All India Congress of Zoology and National Seminar, 21-23 December 2010, Kolkata, India, p. 54-55.

Bhaumik, U., Nath, D., Saha, S., Mitra, A. and Bandhopadhyay, S. 2000. Demonstration of pen culture technology. In: Annual report 1999-2000. Central Inland Fisheries research Institute, Barrackpore, India, p. 57-58.

Chandra, G., Sharma, A. P. and Sahu, S. K. 2013. Impact of penculture technology on fish productivity of wetlands of Asom. J. Inland Fish. Soc. India, 83(2): 209-215.

Deepa, R. S. and Ramachandra, T. V. 2000. Impact of urbanisation on the interconnectivity of wetlands. In: Proceedings of the National symposium on remote sensing applications for natural resources: Retrospective and perspective, 19-21 January, 1999. Indian Society of Remote Sensing, Bangalore, India, p. 343-351.

Giresha, O., Basavaraju, N., Tyagi, A. C. and Shanmukha, S. N. 2003. Carrying capacity models and environmental impact. FAO Fisheries Technical Paper 255, FAO, Rome, Italy, $131 \mathrm{pp}$. 
Gorai, B. K., Bhattacharjya, K. K. and Sarma, K. K. 2010. Pen culture for rearing Indian major carp fingerings in Samaguri Beel, Nagaon District, Assam, India. In: Das, M. K., Katiha, P. K., Mohanty, B. P., Manna, S. K. Majumdar, S., Sunita, P. and Srivastava, P. (Eds.), Book of Abstracts, $21^{\text {st }}$ All India congress of Zoology and National Seminar, 21-23 December 2010, Kolkata, India, 38 pp.

Gorai, B. K., Sugunan, V. V. and Jha, B. C. 2006. Raising of stocking materials of Indian major carps in pen enclosures in selected floodplain wetlands of Assam, India. Asian Fish. Sci., 19: $185-197$

Jha, B. C. 1989. Beel fishery resource in Bihar and Uttar Pradesh. Bull. No. 63, Central Inland Fisheries Research Institute, Kolkata, India, p. 15-28.

Jha, B. C. 1997. Salient ecological features of the Mauns and Chaurs of Bihar and their fisheries. Bull. No. 75, Central Inland Fisheries Research Institute, Kolkata, India, p. 167-174.

Joshi, K. D. and Kumar, D. 2009. Status of fishery, its management and scope for enhancement in a terai Wetland of Uttar Pradesh, India. Asian Fish. Sci., 22: 229-234.

Kathia, P. K., Dutta, S. and Barik, N. K. 2005. Pen culture for fish seed rearing in beels of Assam: Economics and constraints. J. Inland Fish. Soc. India, 37(1): 23-29.

Kumar, D and Joshi, K. D. 2008. Status of fishery and its management in certain wetlands of Uttar Pradesh. $J$. Inland Fish. Soc. India, 40(2): 56-60.

Pathak, V. 1989. Limnological features in beels - Abiotic factors. Bull. No. 63, Central Inland Fisheries Research Institute, Kolkata, India, p. 43-53
Pathak, V. 1990. A comparative study of energy dynamics of open and closed beels in Ganga and Brahmaputra basins. J. Inland Fish. Soc. India, 22(1 \& 2): 26-30.

Pathak, V., Saha, S. B. and Bhagat, M. J. 1985. Pattern of energy utilisation and productivity in beel ecosystem. J. Hydrobiol., 1(2): 47-52.

Pathak, V., Singh, B., Mahavar, L. R. and Saroj, B. D. 2002 A comparative study of hydrological status and energy dynamics of beels in eastern Uttar Pradesh. Proc. Nat. Acad. Sci. India, 72B(1): 47-57.

Pathak, V., Tyagi, R. K. and Singh, B. 2004. Ecological status and production dynamics of wetlands of Uttar Pradesh. Bull. No. 131, Central Inland Fisheries Research Institute, Kolkata, India, p. 44.

Sharma, A. P. 2010. Potentiality of enclosed fish farming in inland waters. In: Bandopadhyay, M. K., Hassan, M. A. and Roy, A. (Eds.), Training manual of pen and cage culture in Inland waters. Central Inland Fisheries Research Institute, Barrackpore, p. 85-90.

Sinha, M. and Khan, M. A. 2001. Impact of the environmental aberration on the fisheries of the Ganga (Ganges) River. Aquat. Ecosyst. Health Manag., 4(4): 493-504.

Sugunan, V. V. 1995. Floodplain wetlands - A fisheries perspective Conservation and sustainable use of floodplain wetlands. Asian Wetland Bureau, Kualalumpur, AWB publication, 113: 13-15.

Sugunan, V. V. 1997. Floodplain wetlands, small water bodies, culture-based fisheries and enhancement - conceptual framework and definition. Bull. 75. Central Inland Fisheries Research Institute, Kolkata, India, p. 13-22. 